\title{
Synthesis, Characterization and Performance Evaluation of an Advanced Solid Electrolyte and Air Cathode for Rechargeable Lithium-Air Batteries
}

\author{
Susanta K. Das ${ }^{1 *}$, Jianfang Chai², Salma Rahman², Abhijit Sarkar ${ }^{2}$ \\ ${ }^{1}$ Department of Mechanical Engineering, Kettering University, Flint, Michigan, USA \\ ${ }^{2}$ Michigan Molecular Institute, Midland, Michigan, USA \\ Email: "sdas@kettering.edu
}

Received 1 December 2015; accepted 5 January 2016; published 11 January 2016

\begin{abstract}
Synthesis and characterization of a tri-layered solid electrolyte and oxygen permeable solid air cathode for lithium-air battery cells were carried out in this investigation. Detailed fabrication procedures for solid electrolyte, air cathode and real-world lithium-air battery cell are described. Materials characterizations were performed through FTIR and TGA measurement. Based on the experimental four-probe conductivity measurement, it was found that the tri-layered solid electrolyte has a very high conductivity at room temperature, $23^{\circ} \mathrm{C}$, and it can be reached up to 6 times higher at $100^{\circ} \mathrm{C}$. Fabrication of real-world lithium-air button cells was performed using the synthesized tri-layered solid electrolyte, an oxygen permeable air cathode, and a metallic lithium anode. The lithium-air button cells were tested under dry air with $0.1 \mathrm{~mA}-0.2 \mathrm{~mA}$ discharge/ charge current at elevated temperatures. Experimental results showed that the lithium-air cell performance is very sensitive to the oxygen concentration in the air cathode. The experimental results also revealed that the cell resistance was very large at room temperature but decreased rapidly with increasing temperatures. It was found that the cell resistance was the prime cause to show any significant discharge capacity at room temperature. Experimental results suggested that the lack of robust interfacial contact among solid electrolyte, air cathode and lithium metal anode were the primary factors for the cell's high internal resistances. It was also found that once the cell internal resistance issues were resolved, the discharge curve of the battery cell was much smoother and the cell was able to discharge at above $2.0 \mathrm{~V}$ for up to 40 hours. It indicated that in order to have better performing lithium-air battery cell, interfacial contact resistances issue must have to be resolved very efficiently.
\end{abstract}

\section{Keywords}

Lithium-Air, Solid Electrolyte, Air Cathode, Button Cell, Metallic Lithium

\footnotetext{
"Corresponding author.
}

How to cite this paper: Das, S.K., Chai, J.F., Rahman, S. and Sarkar, A. (2016) Synthesis, Characterization and Performance Evaluation of an Advanced Solid Electrolyte and Air Cathode for Rechargeable Lithium-Air Batteries. Journal of Materials Science and Chemical Engineering, 4, 74-89. http://dx.doi.org/10.4236/msce.2016.41012 


\section{Introduction}

Emission from conventional fossil fuel based combustion engine vehicles has prompted introduction of electric vehicles $(\mathrm{EV})$ or hybrid electric vehicles $(\mathrm{HEV})$ in the transportation sector in order to reduce greenhouse-gas emission and environmental pollution [1] [2]. The principal component of the EV or HEV is the lithium-ion batteries which act as both an energy storage and power supply source [3]. However, during last two decades of steady $10 \%$ to $15 \%$ performance improvement of lithium-ion batteries brought very close to its theoretical energy density limits set by the available energies of cathode and anode materials [4] [5]. Hence, the search for next generation energy storage and power supply systems has been intense worldwide in recent years [6] [7]. Among the myriad electrochemical energy storage technologies explored so far, the lithium-air (Li-air), also known as $\mathrm{Li}-\mathrm{O}_{2}$ battery, has emerged as one of the most promising energy storage technologies with a possibility of having theoretical energy density almost 10 times more than that of conventional lithium-ion batteries [8]-[10]. In most common configuration, a lithium-air battery comprises a lithium-metal anode, an ion conducting electrolyte and an air electrode [11]. Instead of graphite anode used in lithium-ion battery directly lithium metal can be used as an anode in the lithium-air battery which enhanced Li-air battery capacity 10 times higher than that of conventional Li-ion battery. Also oxygen from the air can be absorbed freely into the cathode of Li-air battery leading to a huge reduction in the weight and the cost of the battery [12].

In general, in the Li-air battery, the Li-metal is oxidized with the help of oxidation catalyst at the anode during discharge and released Li-ion into the electrolyte as shown in equation (1).

$$
\mathrm{Li} \rightarrow \mathrm{Li}^{+}+\mathrm{e}^{-}
$$

However, at the cathode, $\mathrm{O}_{2}$ from the atmospheric air enters into the porous cathode and complete the chemical reaction as

$$
2 \mathrm{Li}^{+}+\mathrm{O}_{2}+2 \mathrm{e}^{-} \rightarrow \mathrm{Li}_{2} \mathrm{O}_{2}
$$

and form the product $\mathrm{Li}_{2} \mathrm{O}_{2}$. Even though it seems that the chemical reaction mechanism in the Li-air battery cell is simple but still the Li-air battery system encounters several issues those must need to be resolved such as (i) very low stability of the conventional electrolytes against $\mathrm{Li} / \mathrm{O}_{2}$ reaction products, (ii) the high cell polarization with consequent low energy efficiency and (ii) the short cycle life [13] [14]. In order to improve stability of $\mathrm{Li} / \mathrm{O}_{2}$ discharge-charge reactions, a suitable electrolyte media and air cathode are required for efficient operation of the lithium-air battery. The high performance electrolyte and air cathode must ensure a safe use of the high-energy lithium metal, eliminate flammability risks and associated safety issues due to short-circuit, possible dendrite formation and consequent thermal runaway [15] [16]. Recently, various type of electrolytes such as solid, polymer, gelled and hybrid electrolytes have been employed in the lithium-air battery systems by numerous researchers [17]-[20] including laminated thin film of polymer electrolytes. Polyethylene oxide (PEO) based electrolytes were also used in the lithium-air cell due to its limited polarization, high reversibility and remarkable safety content and the limited presence of side reactions [21] [22]. Even though PEO based electrolytes have good mechanical stability but its low room-temperature conductivity and high interface resistances hinder its applicability [22]. Multiple layered solid electrolytes by combining polymer and ceramic electrolytes may represent a suitable alternative to PEO based electrolytes both in terms of conductivity and interfacial resistances with improved characteristics [23].

In this study, we synthesized a three layered solid electrolyte by combing high performance polymeric-ceramic electrolytes. A high performing oxygen permeable air cathode is also fabricated for application in high energy lithium-air battery. A real-world lithium-air battery cell is fabricated employing developed three layered solid electrolyte, solid metallic lithium anode and high performance oxygen permeable solid air cathode. Multi-layered solid electrolyte and oxygen permeable air cathode materials are characterized by using FTIR, TGA and other associated measurement techniques. Fabricated lithium-air battery cell was experimentally tested under different real-world operating conditions. Detailed description of synthesis of different components of three layered electrolyte, air cathode material and lithium-air battery performance results are presented in the subsequent sections in this paper. The solid configuration of the entire lithium-air battery cell and the absence of volatile and flammable components in the developed battery cell are expected to strongly limit or eliminate possible safety issues. 


\section{Experimental Procedures}

In order to prepare tri-layered solid electrolyte and oxygen permeable solid air cathode, we first synthesis all the required polymers and ceramic discs by using solid-state reaction processes. We synthesized two fluoro-HBPCS polymer materials in order to prepare an oxygen permeable cathode membrane. Syntheses of these two materials are described below.

\subsection{Synthesis of Fluorinated HBPCS 1}

A $1000 \mathrm{~mL}$ 3-neck flask fitted with a mechanical stirrer and a $12.5 \mathrm{~mL}$ pressure-equalized addition funnel was charged with hexadecafluorodecanediol $(10.0 \mathrm{~g}, 21.7 \mathrm{mmol})$, $\mathrm{NaOH}$ pellets $(2.0 \mathrm{~g}, 50.0 \mathrm{mmol})$, benzyltrimethylammonium bromide $(0.72 \mathrm{~g}, 3.2 \mathrm{mmol})$, and $50 \mathrm{~mL}$ of anhydrous tetrahydrofuran (THF). The contents were heated in an oil bath and stirred until the $\mathrm{NaOH}$ pellets dissolved. The addition funnel was charged with allyl bromide $(7.7 \mathrm{~mL}, 10.7 \mathrm{~g}, 8.8 \mathrm{mmol})$, and the flask was returned to the oil bath, which was maintained at $62^{\circ} \mathrm{C}$ $68^{\circ} \mathrm{C}$. The allyl bromide was added dropwise to the reaction mixture over the course of 1 hour under an $\mathrm{N}_{2}$ flow. Heating and stirring were continued overnight for 17 hours. After cooling, the reaction mixture was poured into a $100 \mathrm{~mL}$ beaker filled to $50 \mathrm{~mL}$ with water, and this suspension was extracted three times each with $17 \mathrm{~mL}$ of ethyl acetate. The combined organic extracts were dried over $\mathrm{MgSO}_{4}$, filtered, and the solvents were removed by rotary evaporation. The viscous liquid was distilled at $123^{\circ} \mathrm{C}-124^{\circ} \mathrm{C}$ under a $5-10 \mathrm{~mm} \mathrm{Hg}$ vacuum, and $10.4 \mathrm{~g}$ (19.2 mmol, 88\% yield) of product was recovered in two fractions as hexadecafluorodecanediol diallyl ether. The product hexadecafluorodecanediol diallyl ether was characterized by the Fourier transform infrared spectroscopy (FTIR) spectrum and found a band associated with the vinyl groups.

Hexadecafluorodecanediol diallylether ( $3.0 \mathrm{~g}, 5.53 \mathrm{mmol}$ ) was weighed into a round-bottom flask equipped with a magnetic stirring bar and a cooling condenser. Trifluoropropyltris (dimethylsiloxy) silane (3.0 g, 8.56 mmol) was added followed by $2 \mathrm{~mL}$ of toluene and 2 drops of platinum divinyl tetramethyldisiloxane complex (Karstedt catalyst, $-2 \%$ in xylene). The solution was then heated in an oil bath at $50^{\circ} \mathrm{C}$ for 5 hours at $70^{\circ} \mathrm{C}$ for 18 hours, and then $100^{\circ} \mathrm{C}$ for 3 days until the FTIR spectrum of the reaction mixture indicated the disappearance of bands associated with the vinyl groups. Material or compound $\mathbf{1}$ was obtained as a colorless liquid after unreacted trifluoropropyltris(dimethylsiloxy)silane was removed by Kugelrohr distillation at $120^{\circ} \mathrm{C}$. Schematic of synthesis of material 1 is shown in Figure 1. The prepared material $\mathbf{1}$ was characterized by the FTIR spectrum as shown in Figure 2. From Figure 2, we can clearly see that $2133 \mathrm{~cm}^{-1}(\mathrm{Si}-\mathrm{H}), 1315 \mathrm{~cm}^{-1}\left(\mathrm{CF}_{3}\right), 1261 \mathrm{~cm}^{-1}$ $\left(\mathrm{Si}-\mathrm{CH}_{3}\right), 1150 \mathrm{~cm}^{-1}$ to $1000 \mathrm{~cm}^{-1}\left(\mathrm{CF}_{2}\right.$ and Si-O-Si overlapped) and $776 \mathrm{~cm}^{-1}\left(\mathrm{CF}_{2}\right)$, which indicated no bands associated with the vinyl groups.

\subsection{Synthesis of Fluorinated HBPCS 2}

Synthesized fluorinated-HBPCS 1 was weighed $(2.01 \mathrm{~g})$ into a round-bottom flask equipped with a magnetic stir bar, followed by vinyltrimethoxysilane $(0.58 \mathrm{~g}, 3.9 \mathrm{mmol})$ and $1 \mathrm{~mL}$ of dry toluene. Residual platinum catalyst from the previous step was assumed to be dispersed in the polymer and still active. The reaction mixture was stirred at room temperature for 17 hours overnight in order to get rid of Si-H band completely. Material or compound 2 was obtained as a viscous colorless liquid after the excess vinyltrimethoxysilane was removed under vacuum at $60^{\circ} \mathrm{C}$. Schematic of synthesis of material 1 is shown in Figure 3.

The synthesized fluorinated-HBPCS 2 (i.e. materials 2) was characterized by the FTIR spectrum in order to make sure that there is no strong $\mathrm{Si}-\mathrm{H}$ band. The FTIR spectrum of material $\mathbf{2}$ is shown in Figure 4. From Figure 4, we can see the presence of $1315 \mathrm{~cm}^{-1}\left(\mathrm{CF}_{3}\right), 1262 \mathrm{~cm}^{-1}$ (Si-Me), $1213 \mathrm{~cm}^{-1}$ to $1085 \mathrm{~cm}^{-1}\left(\mathrm{CF}_{2}\right.$ and $\mathrm{Si}-\mathrm{O}-\mathrm{Si}$ overlapped) and $776 \mathrm{~cm}^{-1}\left(\mathrm{CF}_{2}\right)$, which indicated complete disappearance of the strong $\mathrm{Si}-\mathrm{H}$ band in material 2.

\subsection{Fabrication of Oxygen Permeable Membrane for Air Cathode}

Synthesized fluorinated HBPCS 1 and 2 were mixed in a 75/25 volume ratio in a test tube and the resulting mixture was diluted with an equal volume of isopropyl alcohol, followed by the addition of a catalytic amount of dibutyltin dilaurate. The resulting mixture was transferred onto a glass slide with a pipet and was cured for 5 days at room temperature and thermal analysis of the cured material was performed using Thermal gravimetric analysis (TGA) method as shown in Figure 5. From Figure 5, we can see that no weight loss was found until 


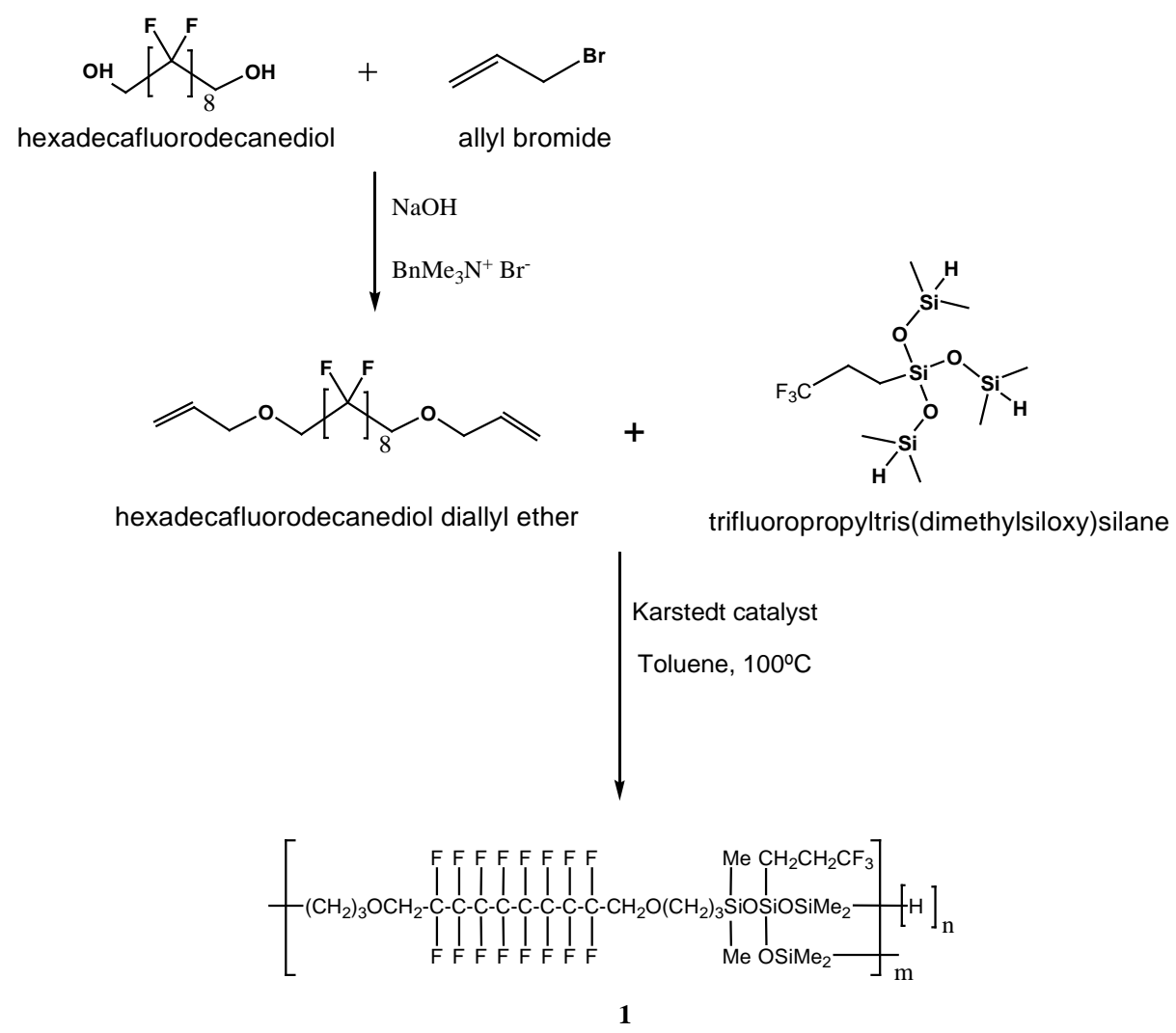

Figure 1. Schematic of synthesis of fluorinated HBPCS 1.

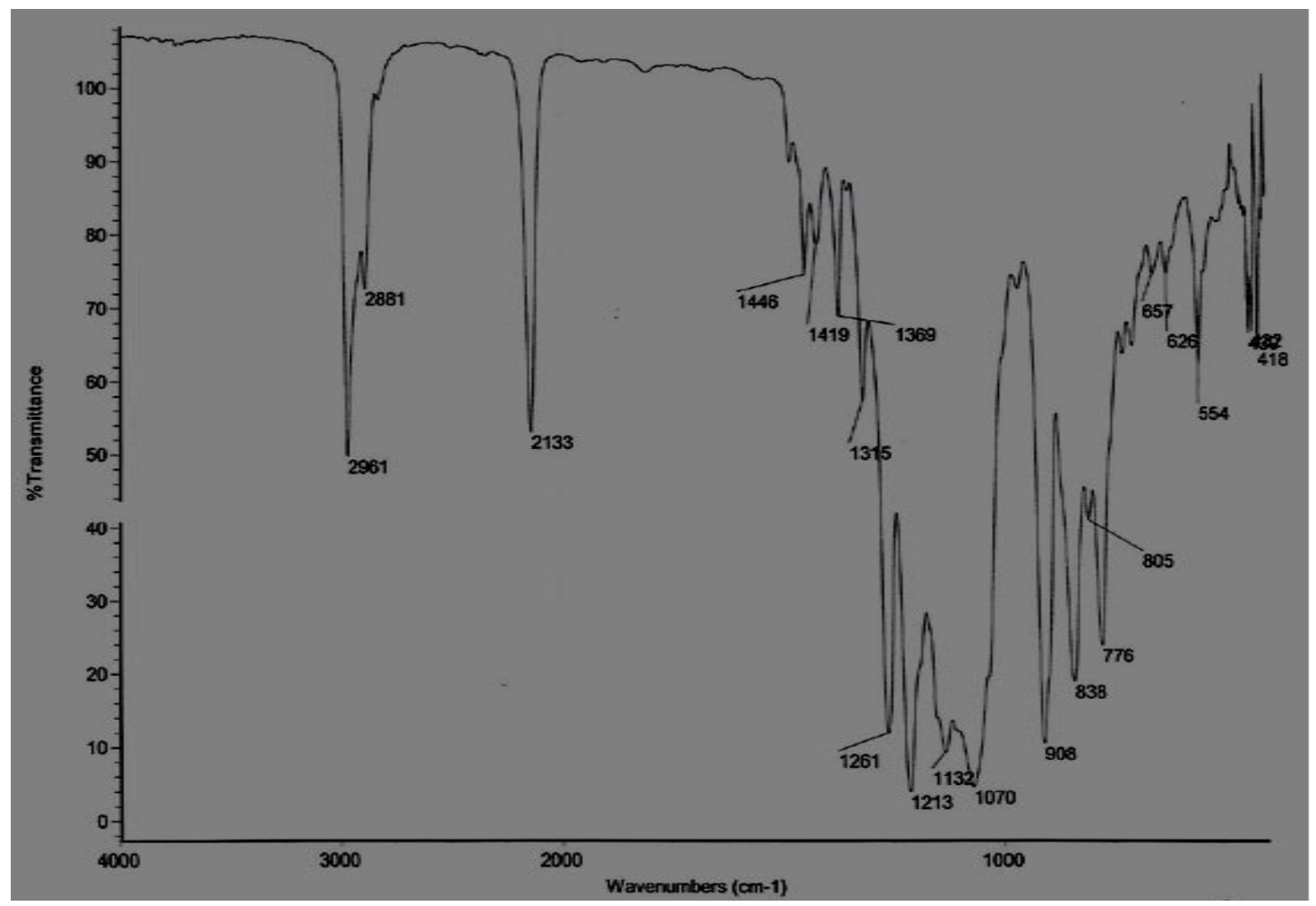

Figure 2. FTIR spectrum of synthesized fluorinated-HBPCS 1 after distillation. 

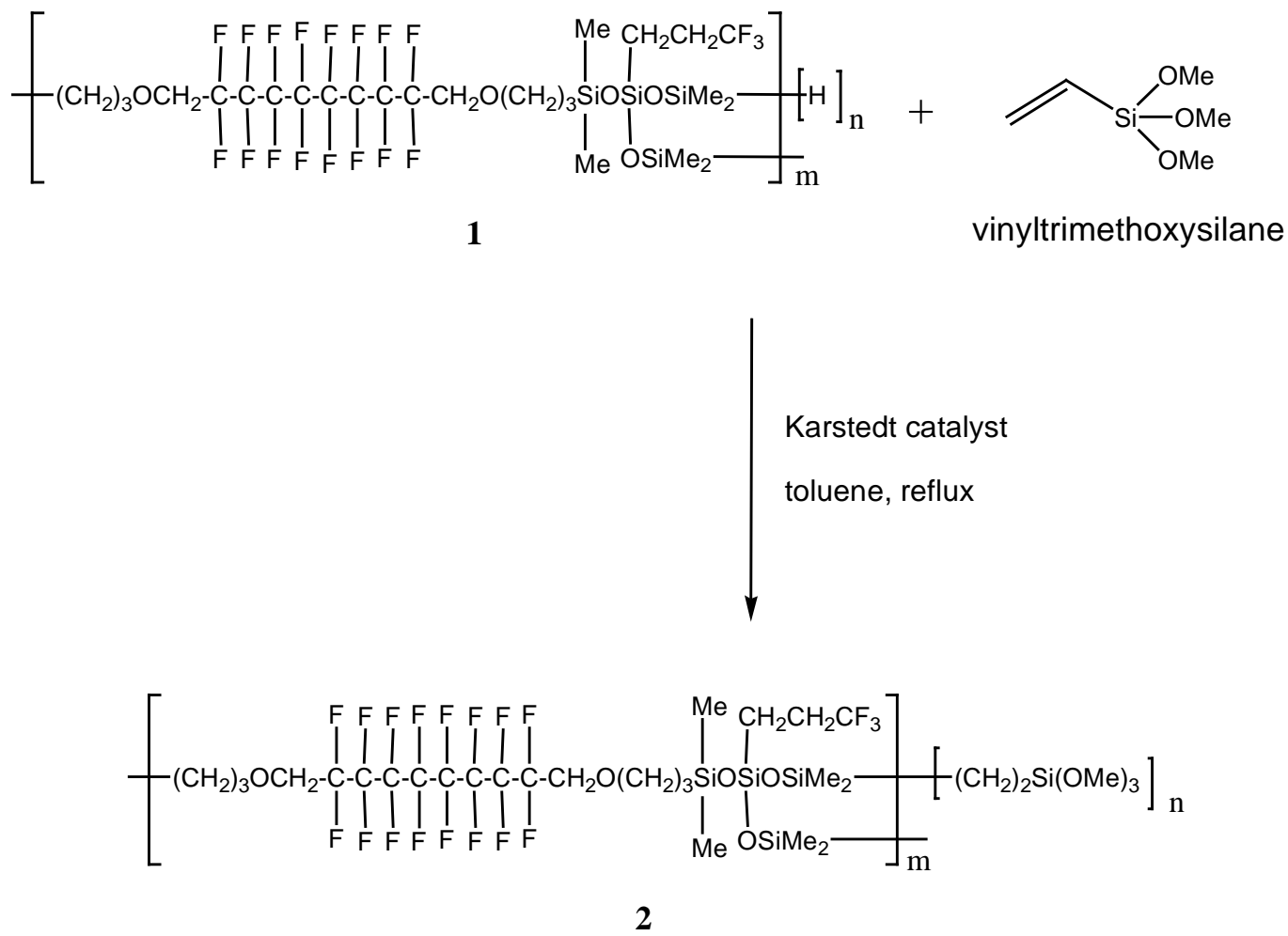

Figure 3. Schematic of synthesis of fluorinated-HBPCS 2.

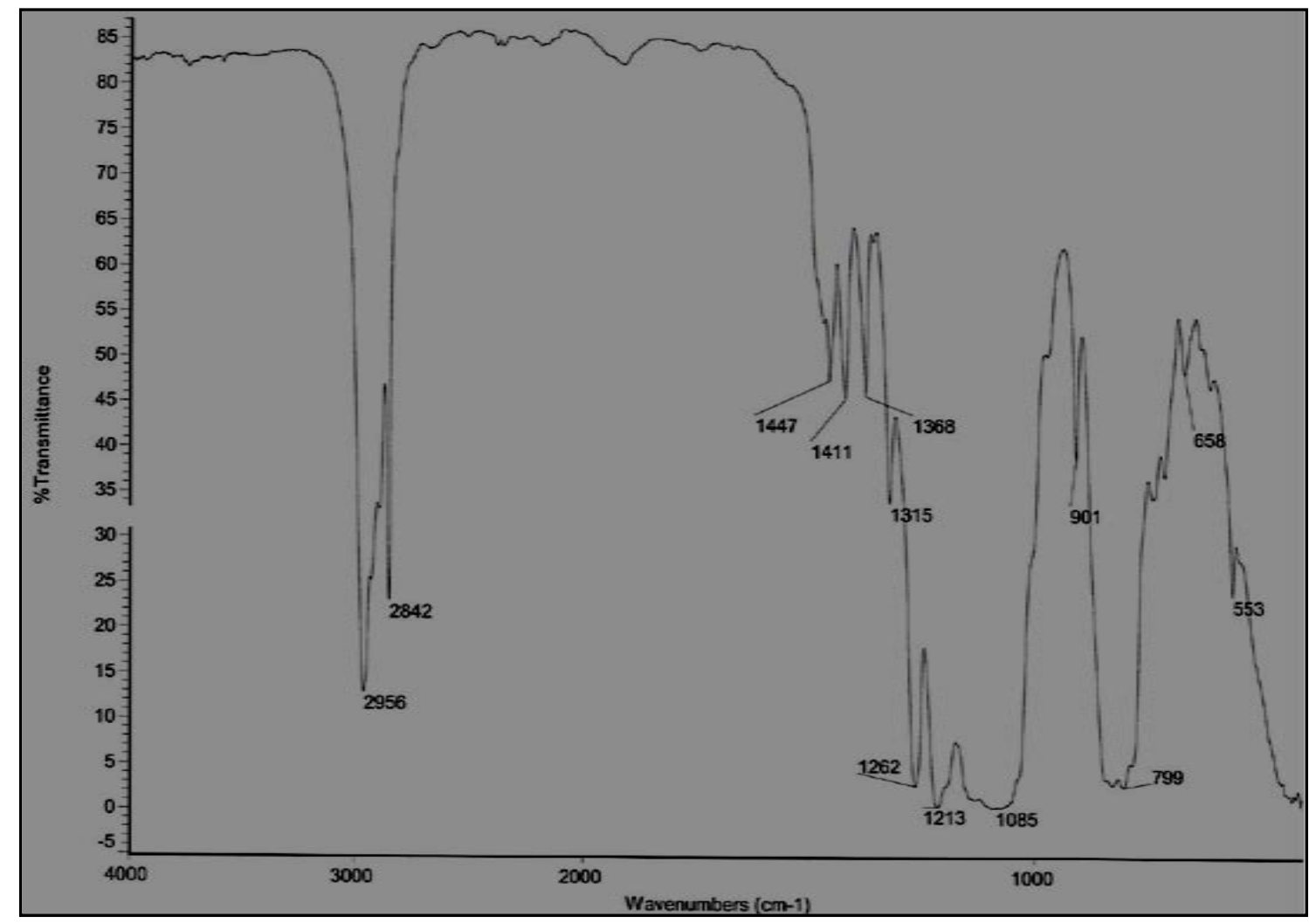

Figure 4. FTIR spectrum of synthesized fluorinated-HBPCS 2 after distillation. 


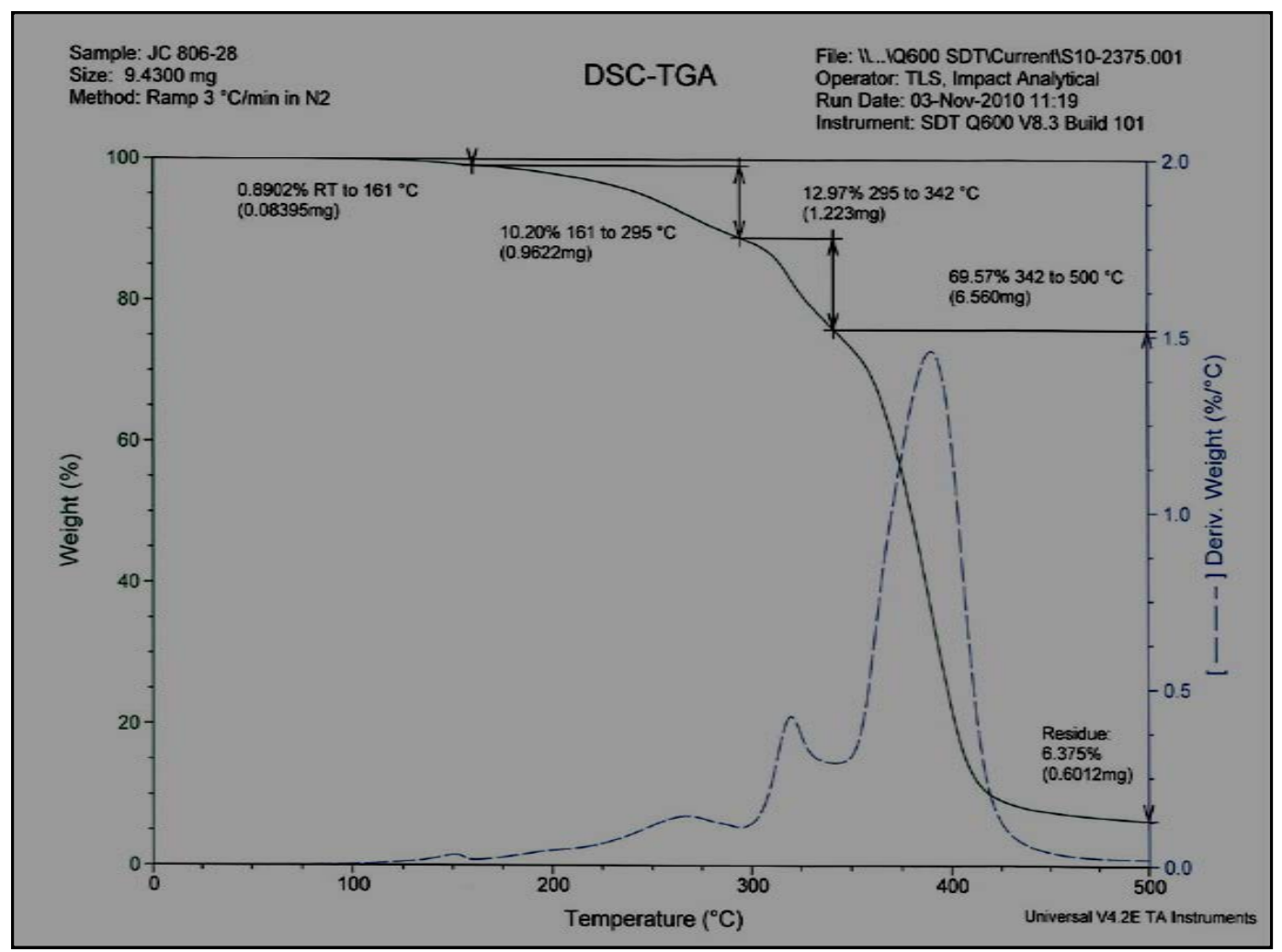

Figure 5. Thermal gravimetric analysis (TGA) weight loss profile of the cured polymer blend (oxygen permeable membrane) from fluorinated HBPCS materials 1 and 2 (75/25 ratio).

$130^{\circ} \mathrm{C}$. Weight loss was increasing slightly with increasing temperature as can be seen from Figure 5. After confirming weight loss of cured polymer blend through TGA, the mixture was then transferred into a $50 \mathrm{~mm}$ diameter dish and a support membrane (PTFE/PP, thickness: $190 \mu \mathrm{m}$, pore size: $0.20 \mu \mathrm{m}$ ) was immersed in the mixture to coat both sides of the membrane. The resulting coated membrane was cured at room temperature for 2 hours followed by curing at $70^{\circ} \mathrm{C}$ for 16 hours and oxygen permeable membrane was prepared that can be used in the air cathode.

\subsection{Preparation of Solid Electrolyte Disc}

Three individual electrolyte discs were prepared to fabricate a three-layered solid ceramic electrolyte laminate. Synthesis method of each individual electrolyte disc is described below.

\subsubsection{Preparation of Polymer Ceramic Boron Nitride, PC (BN) Disc}

Polyethylene oxide (PEO) and lithium bistrifluoromethane sulfonimidate (LiTFSI) were dried at $70^{\circ} \mathrm{C}$ for 48 hours under $\mathrm{N}_{2}$ and transferred to the glove box after drying. PEO (4.25 g), LiTFSI (0.5g), and boron nitride (BN) $(0.047 \mathrm{~g}, 1 \mathrm{wt} \%)$ were weighed in the glove box and mixed in a milling jar. The jar was sealed and taken out of the glovebox for milling. After being milled for 1 hour, the mixture was brought back into the glove box and transferred to a vial. The milled mixture $(200 \mathrm{mg}$ ) was weighed and transferred into a $12 \mathrm{~mm}$ die which was placed on a hot plate set at $95^{\circ} \mathrm{C}$ (the temperature was not uniform) for $10 \mathrm{~min}$ and then pressed with a $19.6 \mathrm{KN}$ force to transform it into a polymer ceramic (PC) membrane. The PC membrane was removed from the die after it had cooled down to room temperature after approximately 1 hour. Four PC(BN) discs were prepared. Once the PC (BN) disc were prepared we measured the thickness of the discs and it was found in the range of $1.21-1.28$ $\mathrm{mm}$.

\subsubsection{Preparation of Polymer Ceramic Lithium Oxide, $\mathrm{PC}\left(\mathrm{Li}_{2} \mathrm{O}\right)$ Disc}

PEO (4.25 g), LiTFSI (0.5 g), and $\mathrm{Li}_{2} \mathrm{O}(0.047 \mathrm{~g}, 1 \mathrm{wt} \%)$ were weighed in the glove box and mixed in a milling 
jar. The jar was sealed and taken out of the glove box for milling. After being milled for 1 hour, the mixture was brought back into the glove box and transferred to a vial. Four PC $\left(\mathrm{Li}_{2} \mathrm{O}\right)$ discs were prepared using a similar procedure as above using $200 \mathrm{mg}$ of the milled mixture.

\subsubsection{Preparation of Lithium Aluminum Germanium Phosphonate, LAGP Ceramic Disc}

Lithium Aluminum Germanium Phosphonate (LAGP) ceramic powder ( $0.45 \mathrm{~g}$ ) was weighed, loaded into a 19 $\mathrm{mm}$ die, and pressed with 9 ton force to obtain a ceramic disc. However, the discs always cracked and it was difficult to obtain a complete un-cracked disc. Part of the reason might be that the pressure on the discs was not uniform and another part of the reason may be due to the material itself (components, particle size, and particle size distribution). Reduction of the LAGP amount from $0.45 \mathrm{~g}$ to $0.30 \mathrm{~g}$ didn't help much although the disc thickness became thinner (from $0.65 \mathrm{~mm}$ to $0.45 \mathrm{~mm}$ ). Preparation of smaller LAGP discs with a $12 \mathrm{~mm}$ die was relatively easier. A lot of effort was applied to improve the quality of the ceramic discs. It was found that addition of a small amount of water $(15-20 \mu \mathrm{L})$ to $0.30 \mathrm{~g}$ of ceramic powder helped to form a complete disc in the die. In addition, the die was pressed with $88.2 \mathrm{KN}$ force several times after turning it $50^{\circ} \mathrm{C}-90^{\circ} \mathrm{C}$ after each pressing in order to minimize the effect of uneven pressure on the disc in a single press. Using this improved procedure, some nice $19 \mathrm{~mm}$ ceramic discs were obtained. These discs were placed on a ceramic plate and transferred to the electric furnace and sintered at $850^{\circ} \mathrm{C}$ for 12 hours. After sintering, the discs were ground down with sandpaper in order to fit in the battery case (2032 button cell). The grinding process was very time consuming (over 1 hour for each disc) and needed to be done very carefully since the discs are very brittle and easy to break. The thickness of the discs was measured and found it would be in the range of $0.42-0.48 \mathrm{~mm}$. The ground discs were placed in a beaker with $30 \mathrm{~mL}$ ethanol and sonicated for $20 \mathrm{~min}$. The discs were then dried in air and transferred to the argon filled glove box for the electrolyte preparation.

\subsection{Preparation of Three-Layered Solid Electrolyte}

A three-layer solid electrolyte was prepared using PC $(\mathrm{BN}), \mathrm{PC}\left(\mathrm{Li}_{2} \mathrm{O}\right)$ and LAGP ceramic discs. Figure 6 shows a sample of each type of disc. In order to prepare a uniform and homogeneous three-layered solid electrolyte, first we prepared same size disc for each type. To do this, we used $19 \mathrm{~mm}$ die for all three types of disc preparation. Then we placed LAGP ceramic disc in between two polymer discs, PC (BN) and PC $\left(\mathrm{Li}_{2} \mathrm{O}\right)$, in order to make sure that the ceramic disc was completely covered by the polymer discs. We aligned all three discs in such a way so that contact areas were aligned perfectly and internal contact resistances were minimized. The three layered disc were then hot press together at $100^{\circ} \mathrm{C}$ on a hot bath and cured afterward and finally obtain a uniformly laminated solid electrolyte.

\subsection{Fabrication of Air Cathode}

In order to prepare a high performance air cathode, we first prepared a cathode paste. To prepare a cathode paste, $0.75 \mathrm{~g}$ of LAGP (Lithium Aluminum Germanium Phosphonate) powder, a lithium ion conductive ceramic powder-obtained from the University of Dayton Research Institute, $0.3 \mathrm{~mL}$ of Darvan CN (an ammonium polymethacrylate), and $4 \mathrm{~mL}$ of DI water were mixed and milled for one hour. An activated carbon mixture ( $0.15 \mathrm{~g}$ of PWA and $0.1 \mathrm{~g}$ of Ketjen Black) and $0.4 \mathrm{~mL}$ of PTFE were added to the milled mixture and milled for another hour. The mixture paste, called cathode paste, was transferred to a vial and stored for use for fabricating the

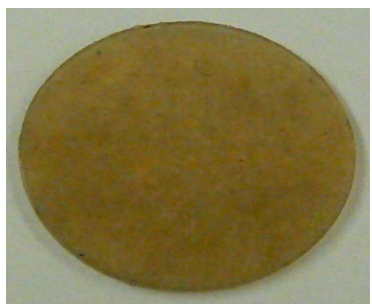

(a)

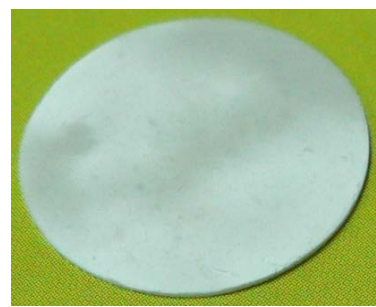

(b)

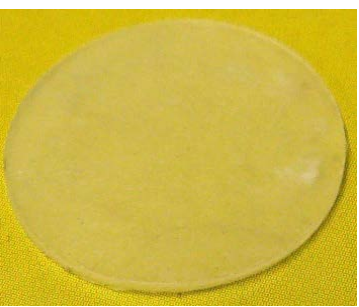

(c)

Figure 6. Components of three layered solid electrolyte. (a) PC(BN) disc; (b) LAGP ceramic disc and (c) $\mathrm{PC}\left(\mathrm{Li}_{2} \mathrm{O}\right)$ disc. 
air cathode. Once cathode pastes were prepared, fabrication of a complete air cathode was followed afterwards. For this, four Ni foam (Novamet, 110 PPI, thickness $1.6 \mathrm{~mm}$, density $420 \mathrm{~g} / \mathrm{m}^{2}$ ) discs were punched from a sheet of material using a $19 \mathrm{~mm}$ punch. The cathode paste, described above, was applied to the nickel foam on one side using a spatula. This Ni foam with the cathode paste was covered with aluminum foil and sandwiched between two stainless steel plates. Then the entire stainless plate was covered with the previously prepared oxygen permeable membrane comprising of fluoro HBPCS and pressed with a $27.4 \mathrm{KN}$ force using a laboratory hydraulic press. Thereafter, these cathode samples were dried at room temperature for 3 days and at $70^{\circ} \mathrm{C}$ for 14 hours. The dried cathodes were weighed and the thicknesses were measured. The cathodes were sintered in an argon atmosphere at $300^{\circ} \mathrm{C}$ for six hours to remove the dispersant and obtain a mechanically stable cathode structure (oven purge rate: $30 \mathrm{SCFH}$ for the first 2 hours, then decreased to $10 \mathrm{SCFH}$ for the rest of the process). After sintering, the cathodes were transferred to an argon purged glove box. The properties of prepared air cathodes are presented in Table 1. From Table 1 we can see that the weight of different samples of air cathode is within the range of $0.15-0.17 \mathrm{~g}$. The weight loss during sintering is between $4.4-6 \mathrm{mg}$ and the thickness of different samples of air cathode vary between $0.25-0.28 \mathrm{~mm}$.

\subsection{Fabrication of Lithium-Air Battery Top cap}

In order to prepare a real-world working lithium-air battery, we purchased IEC standard CR-2032 button cell case from the market place. The top cap of the CR-2032 button cell case needs to have holes present to allow for the introduction of air and/or oxygen to interact with the cathode. The top caps of the CR-2032 button cell cases were drilled with 29 holes using a \#60 drill bit (1.016 mm diameter) using a drill press. A design template was created in Photoshop to uniformly place the holes in the area available. Each point was first indented using a nail and hammer to guide the drill bit to the proper location. The top part of the cap was then smoothed out using a grinding attachment on a Dremel tool.

\subsection{Fabrication of Real-World Lithium-Air Battery}

Button cells (type CR-2032) were assembled in a glove box under an argon atmosphere. The cathode was first placed in a button cell battery case cap with 29 holes drilled in the cap to enable air/oxygen entry. A wave spring, a spacer, and an aluminum foil disc were put in the bottom portion of the battery case in that order. A lithium foil plate ( $20 \mathrm{~mm}$ by $20 \mathrm{~mm}$ ) was cut out from a lithium foil roll and scrubbed with a sharp blade to get rid of the surface lithium oxide layer on both sides. After the surface was cleaned, the lithium foil plate was punched to form a $15 \mathrm{~mm}$ diameter disc and placed on the top of the aluminum foil disc. The lithium foil plate will act as an anode of the button cell battery. The previously prepared three-layer electrolyte laminate was then placed on the top of the lithium disc and the cap with the air cathode was placed on top to cover the bottom portion of the case. The whole assembly was placed into a ziploc bag and taken out of the glove box. Finally, the button cell battery assembly was taken out of the ziploc bag and placed on a button cell crimping machine die and crimped

Table 1. Properties of the prepared air cathode.

\begin{tabular}{|c|c|c|c|c|c|c|c|}
\hline $\begin{array}{l}\text { Sample } \\
\text { number }\end{array}$ & $\begin{array}{c}\text { Ni foam } \\
\text { weight (g) }\end{array}$ & $\begin{array}{c}\text { Ni foam + wet } \\
\text { paste (g) }\end{array}$ & $\begin{array}{l}\text { Ni foam + dry } \\
\text { paste }(g)\end{array}$ & $\begin{array}{c}\text { Dry paste } \\
\text { weight (mg) }\end{array}$ & $\begin{array}{l}\text { Weight after } \\
\text { sintering (g) }\end{array}$ & $\begin{array}{l}\text { Weight lost } \\
\text { uring sintering (mg) }\end{array}$ & $\begin{array}{l}\text { Thickness } \\
\text { (mm) }\end{array}$ \\
\hline JC806-89-01 & 0.1070 & 0.2108 & 0.1542 & 47.2 & 0.1498 & 4.4 & 0.280 \\
\hline JC806-89-02 & 0.1142 & 0.2395 & 0.1677 & 53.5 & 0.1627 & 5.0 & 0.260 \\
\hline JC806-89-03 & 0.1046 & 0.2501 & 0.1557 & 51.1 & 0.1512 & 4.5 & 0.270 \\
\hline JC806-89-04 & 0.1163 & 0.2750 & 0.1789 & 62.6 & 0.1737 & 5.2 & 0.280 \\
\hline JC806-89-05 & 0.1130 & 0.2549 & 0.1665 & 53.5 & 0.1613 & 5.2 & 0.260 \\
\hline JC806-89-06 & 0.1155 & 0.3022 & 0.1710 & 55.5 & 0.1661 & 4.9 & 0.250 \\
\hline JC806-89-07 & 0.1142 & 0.2618 & 0.1746 & 60.4 & 0.1686 & 6.0 & 0.270 \\
\hline JC806-89-08 & 0.1152 & 0.2376 & 0.1670 & 51.8 & 0.1621 & 4.9 & 0.260 \\
\hline JC806-89-09 & 0.1160 & 0.2568 & 0.1715 & 55.5 & 0.1659 & 5.6 & 0.250 \\
\hline
\end{tabular}


quickly to fabricate lithium-air button cell battery. Once fabrication was completed the lithium-air button cell was available for performance evaluation.

\section{Results and Discussions}

To evaluate the overall conductivity of the tri-layered solid electrolyte, we first calculated the activation energy of each component of the tri-layered solid electrolyte in order to understand the temperature and conductivity relationship. To calculate activation energy of the individual component, we used Arrhenius equation as shown in Equation (3).

$$
\sigma=\sigma_{0} e^{-E_{a} / R T}
$$

where $E_{a}, R$ and $T$ are the activation energy, gas constant, and absolute temperature, respectively, and $\sigma$ are the electrolyte conductivity, and $\sigma_{0}$ is pre-exponential factor. Taking the natural logarithm of each side of the Arrhenius equation gives

$$
\ln \sigma=\ln \sigma_{0}-\frac{E_{a}}{R T}
$$

This is a linear equation of $y=m x+b$, where $x=1 / T$ and $m=-E_{d} / R=$ slope.

Figure 7 represents Arrhenius plot of each component of three-layered solid electrolyte. From Figure 7 we can see that, at room temperature $\left(23^{\circ} \mathrm{C}\right)$, the ceramic LAGP disc has the highest conductivity of $\sigma=3.29 \times 10^{-4}(\mathrm{~S} / \mathrm{cm})$ compared to the polymer disc $\mathrm{PC}(\mathrm{BN})$ and $\mathrm{PC}\left(\mathrm{Li}_{2} \mathrm{O}\right)$. We also see that the polymer disc PC $\left(\mathrm{Li}_{2} \mathrm{O}\right)$ has the lowest conductivity of $\sigma=1.92 \times 10^{-4}(\mathrm{~S} / \mathrm{cm})$ at room temperature $\left(23^{\circ} \mathrm{C}\right)$. It is noted that the polymer discs are used to provide improved mechanical and thermal support to the ceramic disc so that the three layered solid electrolyte will have better durability and thermal stability.

Figure 8 represents conductivity of the solid electrolyte as a function of temperature. The conductivity of the solid electrolyte was measured using standard four-probe electrodes technique. From Figure 8 we can see that solid electrolyte has the conductivity of $\sigma=3.18 \times 10^{-4}(\mathrm{~S} / \mathrm{cm})$ at room temperature $\left(23^{\circ} \mathrm{C}\right)$ compared to $\sigma=3.29 \times 10^{-4}(\mathrm{~S} / \mathrm{cm})$ of the ceramic disc LAGP as shown in Figure 8. The slight decrease of the conductivity of the solid electrolyte at room temperature is due to the laminated layers of polymer discs PC (BN) and PC $\left(\mathrm{Li}_{2} \mathrm{O}\right)$. Due to the strong brittle nature of LAGP ceramic discs, we used strong polymeric discs of PC (BN) and PC $\left(\mathrm{Li}_{2} \mathrm{O}\right)$ to provide strong mechanical and thermal support of the solid electrolyte. Strong mechanical and thermal strength of solid electrolyte will ensure safe use of the high-energy lithium metal at the anode, eliminate flammability risks and associated safety issues due to short-circuit, possible dendrite formation and consequent thermal runaway. We can see from Figure 8 that the conductivity of the solid electrolyte increases sharply with the increase of temperature. For example, the conductivity of the solid electrolyte is about $\sigma=18.12 \times 10^{-4}(\mathrm{~S} / \mathrm{cm})$ at $100^{\circ} \mathrm{C}$ which is almost 6 times higher than the conductivity at room temperature. It implies that it would be possible to operate the battery cell at a higher temperature, if needed, for enhanced electro-kinetics within the cell.

\section{Lithium-Air Button Cell Testing and Performance Evaluation}

Lithium-air button cells were fabricated utilizing the Ni/C/LAGP based cathode, the PC $\left(\mathrm{Li}_{2} \mathrm{O}\right) / \mathrm{LAGP} / \mathrm{PC}(\mathrm{BN})$ based solid electrolyte, and a lithium metal anode. The cells were tested under dry air with $0.1 \mathrm{~mA}$ discharge/charge current at elevated temperatures.

In a lithium-air cell, the cathode is comprised of ionic and electronic conductors. In order to optimize the cell performance, the composition of ionic and electronic conductors must be in a proper ratio. It is very evident that the ratio may affect both physical properties such as surface area, pore volume, and porosity of the cathode as well as electrochemical properties such as cell capacity, cell impedance, energy density, and power density of the cell. To assess the effect of the cathode composition, three different cathodes were prepared with different LAGP (ionic conductor)/C (electronic conductor) ratios 75/25, 50/50 and 25/75. In addition, it is known that catalysts can enhance the $\mathrm{Li}$-air cell performance since the oxygen reduction reaction is normally very slow. Thus, commercial $\mathrm{Co}_{3} \mathrm{O}_{4}$ nano-powder was explored as a catalyst. In total, five air cathodes were fabricated and five lithium-air button cells had been assembled using these cathodes while keeping other parameters constant.

Table 2 and Figure 9 and Figure 10show the cell performance of three different types cathodes assembled in 


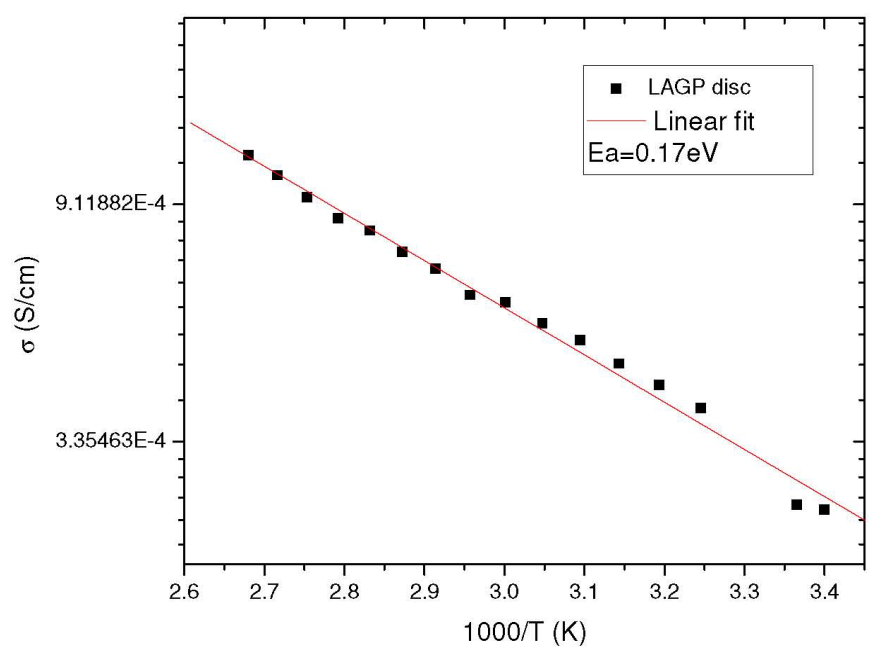

(a)

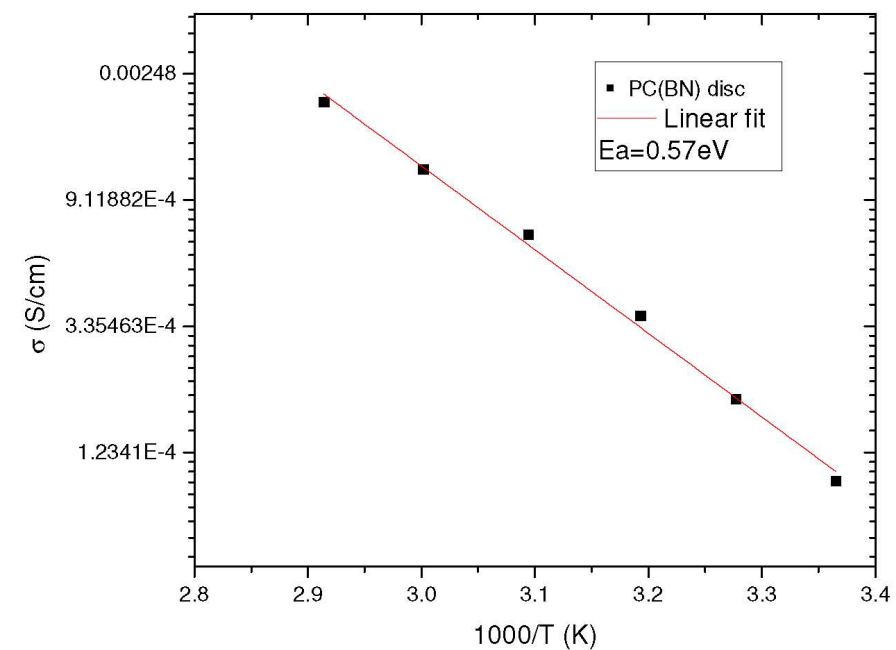

(b)

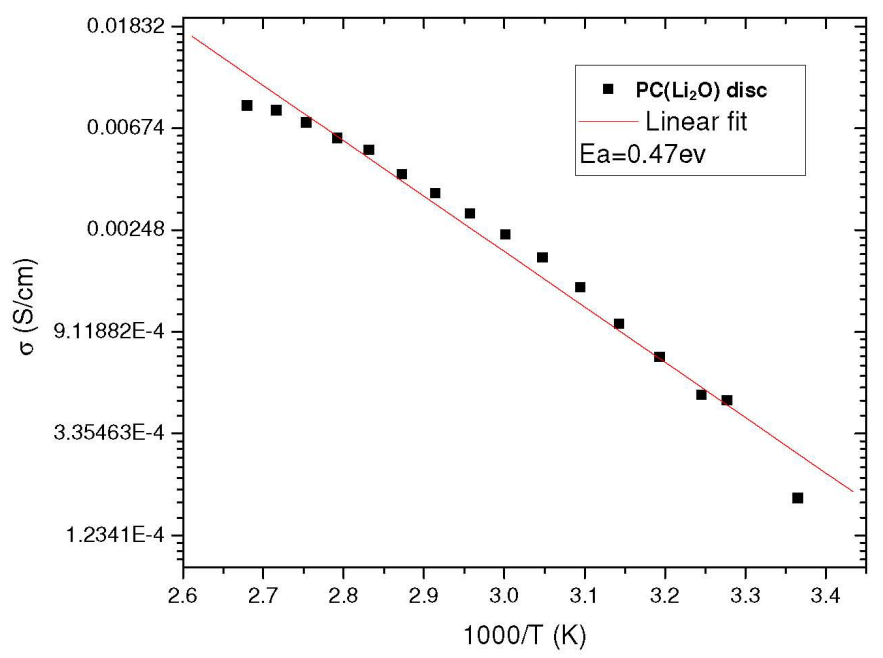

(c)

Figure 7. Arrhenius plot of each component of three layered solid electrolyte. (a) LAGP ceramic disc, (b) $\mathrm{PC}(\mathrm{BN})$ disc and (c) $\mathrm{PC}\left(\mathrm{Li}_{2} \mathrm{O}\right)$ disc. 


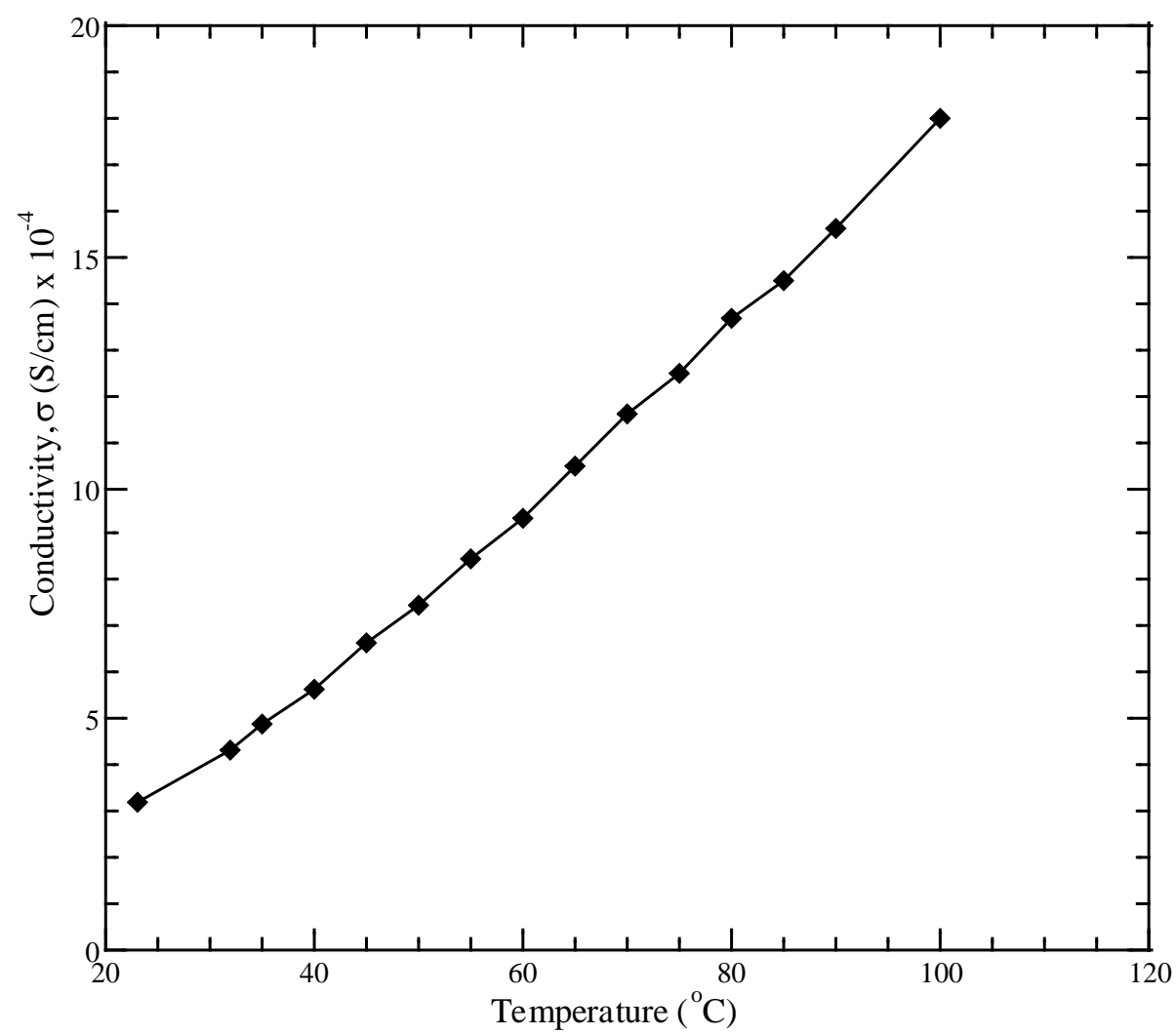

Figure 8. Measured conductivity of the solid electrolyte as a function of temperature.

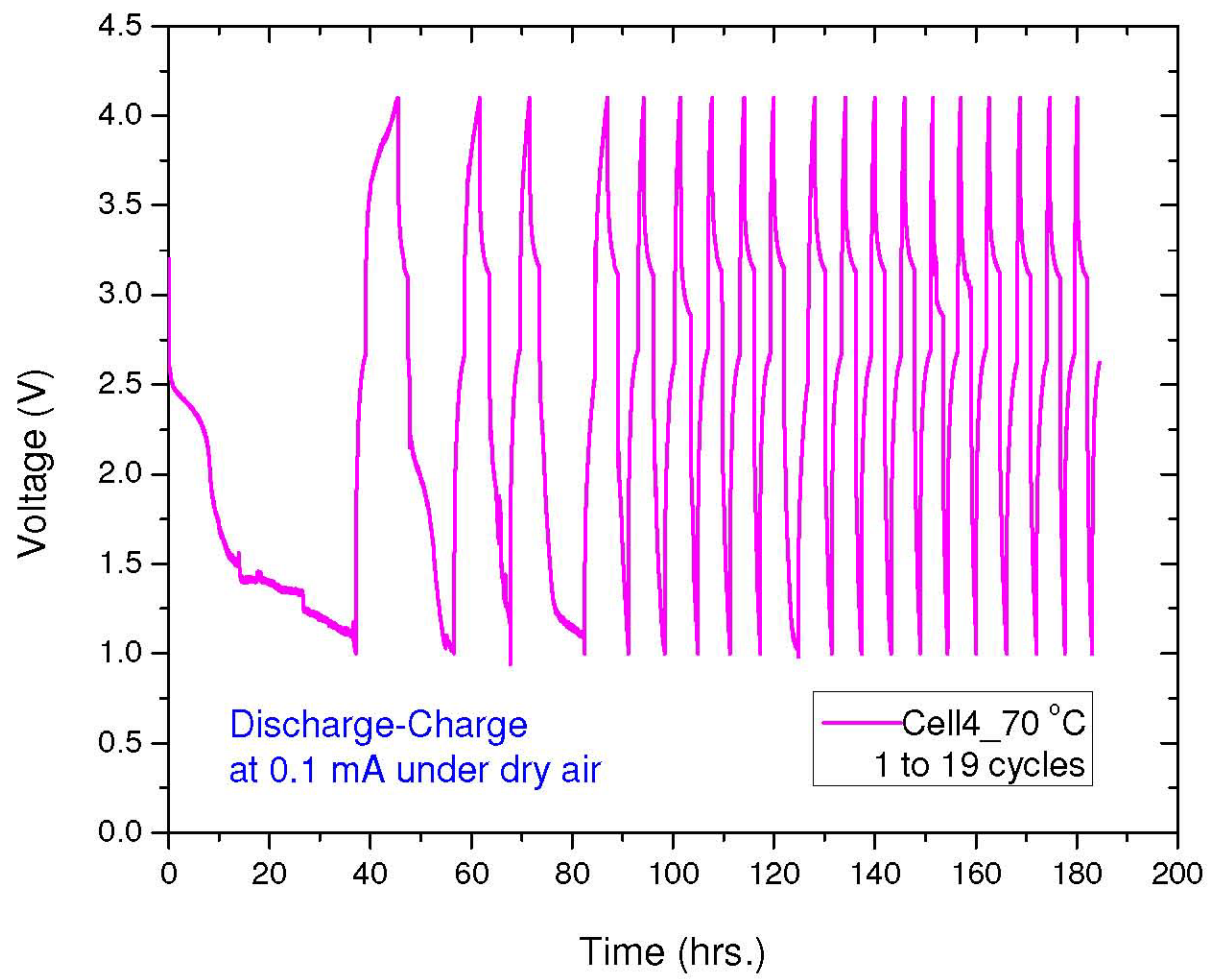

Figure 9. Discharge/charge characteristics of cell 4. 


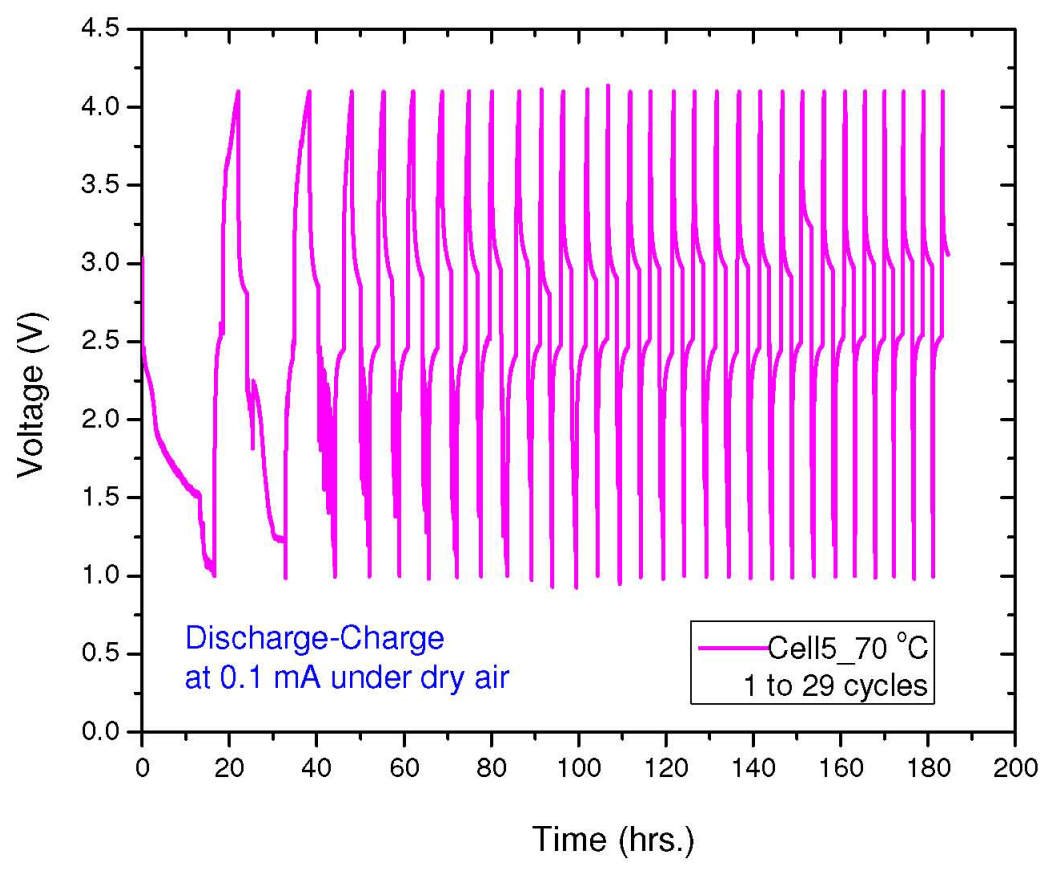

Figure 10. Discharge/charge characteristics of cell 5.

Table 2. Cell performances with different cathode compositions are shown. *The first number corresponds to the capacity at a $1.5 \mathrm{~V}$ cut off voltage; the second corresponds to the capacity at a $1.0 \mathrm{~V}$ cut off voltage. Test conditions: $70^{\circ} \mathrm{C}$ except cell 6 at $80^{\circ} \mathrm{C}$, discharge/charge current $0.1 \mathrm{~mA}$ under dry air

\begin{tabular}{|c|c|c|c|c|c|c|c|}
\hline \multicolumn{2}{|c|}{ Cell number } & Cell 4 & Cell 5 & Cell 6 & Cell 806-188-2 & Cell 806-188-3 & Cell 816-19-1 \\
\hline \multicolumn{2}{|c|}{$\begin{array}{l}\text { LAGP/C ratio } \\
\text { in the cathode }\end{array}$} & $75 / 25$ & $75 / 25$ & $75 / 25$ & $50 / 50$ & $50 / 50$ & $25 / 75$ \\
\hline \multicolumn{2}{|c|}{ Catalyst } & none & none & $\mathrm{Co}_{3} \mathrm{O}_{4}$ & none & $\mathrm{Co}_{3} \mathrm{O}_{4}$ & none \\
\hline \multirow{6}{*}{$\begin{array}{l}\text { Capacity } \\
(\mathrm{mAh})^{*}\end{array}$} & 1c & 1.4/3.7 & 1.3/1.6 & 1.6 & $2.0 / 11.0$ & $7.0 / 20.0$ & \multirow{6}{*}{$\begin{array}{l}\text { Submitted } \\
\text { for testing }\end{array}$} \\
\hline & 2c & $0.4 / 0.7$ & $0.7 / 0.9$ & $1.5 / 1.7$ & 5.0 & 4.5 & \\
\hline & 3c & $0.2 / 0.4$ & $0.3 / 0.4$ & $0.7 / 0.9$ & $2.1(2 \mathrm{~V})$ & \multirow{4}{*}{$\begin{array}{l}\text { Increased } \\
\text { current to } 0.2 \mathrm{~mA} \text {, } \\
\text { and the cell died }\end{array}$} & \\
\hline & 4c & $0.4 / 0.7$ & $0.2 / 0.2$ & $0.5 / 0.7$ & $1.0(2 \mathrm{~V})$ & & \\
\hline & $5 c$ & $0.1 / 0.2$ & $0.2 / 0.2$ & $0.2 / 0.3$ & $1.0(2 \mathrm{~V})$ & & \\
\hline & 6c & $0.1 / 0.2$ & $0.2 / 0.2$ & $0.3 / 0.3$ & - & & \\
\hline \multicolumn{2}{|c|}{$\begin{array}{l}\text { Specific capacity } \\
\text { (mAh/gC) }\end{array}$} & $152 / 402$ & $125 / 154$ & 160 & $103 / 567$ & $407 / 1163$ & $\begin{array}{l}\text { Submitted } \\
\text { for testing }\end{array}$ \\
\hline
\end{tabular}

the button cells. From Table 2 and Figure 9 and Figure 10 we can see that the cell capacity with a 75/25 LAGP/C cathode varied from 1.3 - 1.6 mAh and it was increased to $2.0 \mathrm{mAh}$ for cell 806-188-2 with an increase of the $\mathrm{C}$ content. As expected, the introduction of $\mathrm{Co}_{3} \mathrm{O}_{4}$ greatly enhanced the cell performance and the cell capacity jumped from $2.0 \mathrm{mAh}$ to $7.0 \mathrm{mAh}$, as can be seen for cell 806-188-3, with the specific capacity reaching over $1100 \mathrm{mAh} / \mathrm{gC}$. The first discharge curves of the cells 4 and 5, Figure 9 and Figure 10, showed two plateaus, one was between 4.0 to $1.5 \mathrm{~V}$, while the second one was between 1.5 to $1.0 \mathrm{~V}$, which might correspond to different reactions. The rechargeability of all of these 6 cells as shown in Table 2 was poor and $80 \%$ of the capacity was lost within 5 cycles.

In order to know the effect of oxygen availability or concentration in the air cathode of lithium-air battery, the battery cell was tested in a partially sealed Ziploc plastic bag which was connected to a dry air cylinder. The Ziploc bag was placed in a temperature controllable oven and the temperature of the oven was kept at the de- 
sired value during the test. Figure 11 shows first discharge profile of cell 6 tested under controlled air flow at $80^{\circ} \mathrm{C}$. From Figure 11 we can see that as the cell voltage dropped quickly as the air flow reduced to the cathode of the lithium-air button cell. It indicates that the cell voltage was very sensitive to the air flow rate. As the air flow adjusted to the appropriate level the cell shows monotonous discharge pattern as it should be expected. These characteristics of the cell indicate that the cell performance is very sensitive to the oxygen concentration in the cathode.

As shown in Table 2, in the case of cells 188-2 and 188-3, a higher discharge current (0.2 mA) was tried and we found that the cells died quickly. We were curious to explore what causes the cells died so quickly. It was found that cell performance largely depends on the cell internal resistance [24]. Thus, in order to evaluate the cell's internal resistance, several cells were fabricated with Li metal as both the cathode and the anode as well as using a single layer polymer electrolyte instead of the PC $\left(\mathrm{Li}_{2} \mathrm{O}\right) / \mathrm{LAGP} / \mathrm{PC}(\mathrm{BN})$ tri-layer electrolyte except our previously tested cell 6 . We measured each cell resistance at different temperatures.

As shown in Table 3, the cell resistance was very large at room temperature but decreased rapidly with increasing temperature. This explains why the cells did not show any significant discharge capacity at room tem-

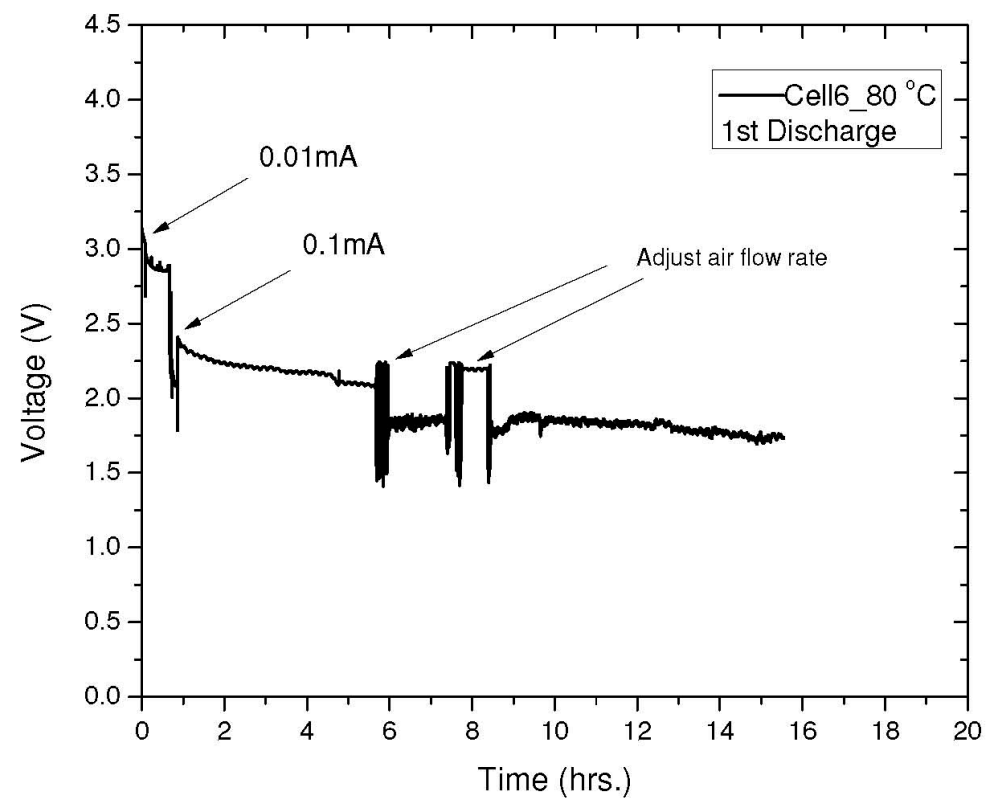

Figure 11. Discharge/charge characteristics of cell 6.

Table 3. Measured lithium-air button cell’s internal resistance at different temperatures.

\begin{tabular}{|c|c|c|c|c|c|}
\hline Sample & Cathode & Electrolyte & Anode & Temp. $\left({ }^{\circ} \mathrm{C}\right)$ & Resistance (ohm) \\
\hline JC806-126-T1 & $\mathrm{Li}$ & $\mathrm{PC}(\mathrm{BN}) / \mathrm{LAGP} / \mathrm{PC}\left(\mathrm{Li}_{2} \mathrm{O}\right)$ & $\mathrm{Li}$ & $\begin{array}{l}24 \\
60 \\
70 \\
80\end{array}$ & $\begin{array}{c}-2000 \\
170 \\
120 \\
72.6\end{array}$ \\
\hline JC806-126-T2 & $\mathrm{Li}$ & $\mathrm{PC}(\mathrm{BN}) / \mathrm{LAGP} / \mathrm{PC}\left(\mathrm{Li}_{2} \mathrm{O}\right)$ & $\mathrm{Li}$ & $\begin{array}{l}24 \\
60 \\
70 \\
80\end{array}$ & $\begin{array}{c}-2000 \\
184 \\
96.0 \\
70.0\end{array}$ \\
\hline JC806-126-S1 & $\mathrm{Li}$ & Single layer $\mathrm{PC}\left(\mathrm{Li}_{2} \mathrm{O}\right)$ & $\mathrm{Li}$ & $\begin{array}{l}24 \\
60 \\
70 \\
80\end{array}$ & $\begin{array}{c}-3000 \\
190 \\
145 \\
105\end{array}$ \\
\hline JC806-126-S2 & $\mathrm{Li}$ & Single layer $\mathrm{PC}\left(\mathrm{Li}_{2} \mathrm{O}\right)$ & $\mathrm{Li}$ & 24 & -2000 \\
\hline Cell 6 & 75/25 LAGP/C & $\mathrm{PC}(\mathrm{BN}) / \mathrm{LAGP} / \mathrm{PC}\left(\mathrm{Li}_{2} \mathrm{O}\right)$ & $\mathrm{Li}$ & $\begin{array}{l}23 \\
60 \\
80\end{array}$ & $\begin{array}{c}3350 \\
320 \\
84\end{array}$ \\
\hline
\end{tabular}


perature while performing much better at elevated temperature as shown in Figures 9-11. Surprisingly, the replacement of the tri-layer electrolyte with only one polymer layer didn't decrease the resistance, although the thickness of the electrolyte was reduced to less than one-third as can be seen from Table 3 . This indicates that the interfaces of different layers are the primary factor for the cell's high internal resistance.

In order to verify the interfacial contact resistance problem, a cell was fabricated with a 75/25 LAGP/C cathode without $\mathrm{Co}_{3} \mathrm{O}_{4}$ catalyst, a $\mathrm{PC}\left(\mathrm{Li}_{2} \mathrm{O}\right) / \mathrm{LAGP} / \mathrm{PC}(\mathrm{BN})$ solid electrolyte, and a $\mathrm{Li}$ metal anode - just similar to the cell 6 but with no $\mathrm{Co}_{3} \mathrm{O}_{4}$ catalyst. The interface of $\mathrm{Li}$ and the electrolyte was wetted with a silicon containing electrolyte (1.0 M LiTFSI in $\mathrm{MeC}(\mathrm{O}) \mathrm{OCH}_{2} \mathrm{CH}_{2} \mathrm{SiMe}_{2} \mathrm{O}\left(\mathrm{CH}_{2} \mathrm{CH}_{2} \mathrm{O}\right){ }_{3} \mathrm{Me}$, conductivity: $\left.7.0 \times 10^{-4} \mathrm{~S} / \mathrm{cm}\right)$ to make better contact with the electrolyte. The properties of the new cell, JC806-188-1, is presented in Table 4. The discharge/charge characteristics of the newly fabricated cell, JC806-188-1, is presented in Figure 12. Compared to cells 4 - 6 shown in Figures 9-11 those were without wetting interfaces, the cell capacity of the newly fabricated cell (Cell ID: JC806-188-1 shown in Table 4) increased by a factor of 4 (see Table 3 and Table 4). In addition, it can be seen from Figure 12 that the discharge curve of this cell (JC806-188-1) was much smoother than that of cells 4 - 6 shown in Figures 9-11. It should be pointed out that the new cell, JC806-188-1, was discharged above $2.0 \mathrm{~V}$ for up to 40 hours as can be seen from Figure 12. This result indicates that in order to obtain a better performing lithium-air battery cell we must have to resolve interfacial contact resistances issue very efficiently. Also, it is important to ensure establishment of robust contact between electrolyte and electrodes for obtaining better performance from lithium-air battery cell.

\section{Conclusions}

A tri-layered solid electrolyte and air cathode for lithium-air battery was synthesized using high performance ionic and electronic conductive materials. Characterization of solid electrolyte and air cathode materials were performed through FTIR and TGA measurement. Detailed fabrication procedures for solid electrolyte, air cathode

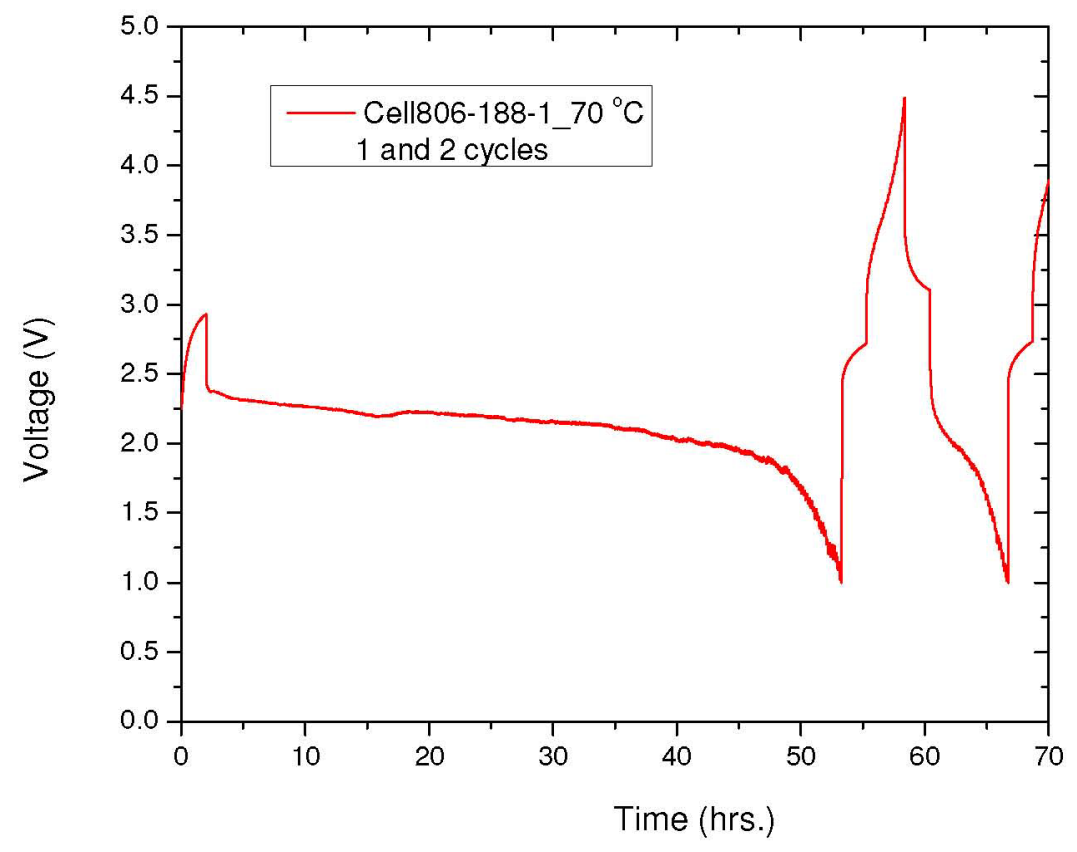

Figure 12. Discharge/charge characteristics of a lithium-air button cell (JC806-188-1).

Table 4. Properties of new lithium-air cell, JC806-188-1.

\begin{tabular}{|c|c|c|c|c|c|}
\hline Cell number & Cathode composition & Electrolyte & Anode & Capacity (mAh) & Specific capacity (mAh/gC) \\
\hline JC806-188-1 & $\begin{array}{c}\text { 75/25 LAGP/C } \\
\text { No catalyst }\end{array}$ & $\mathrm{PC}\left(\mathrm{Li}_{2} \mathrm{O}\right) / \mathrm{LAGP} / \mathrm{PC}(\mathrm{BN})$ & $\mathrm{Li}$ & 5.1 & 331 \\
\hline
\end{tabular}


and real-world lithium-air battery cell were discussed in this paper. Based on experimental four-probe conductivity measurement, it was found that the tri-layered solid electrolyte possesses a very high conductivity of $\sigma=3.18 \times 10^{-4}(\mathrm{~S} / \mathrm{cm})$ at room temperature $\left(23^{\circ} \mathrm{C}\right)$ and it can be reached 6 times ${ }^{\circ} \mathrm{C}$ higher conductivity at $100^{\circ} \mathrm{C}$ compared to room temperature. Real-world lithium-air button cells were fabricated utilizing tri-layered solid electrolyte based on PC $\left(\mathrm{Li}_{2} \mathrm{O}\right) / \mathrm{LAGP} / \mathrm{PC}(\mathrm{BN})$, a high performance air cathode based on Ni/C/LAGP, and a lithium metal anode. The cells were tested under dry air with $0.1 \mathrm{~mA}-0.2 \mathrm{~mA}$ discharge/charge current at elevated temperatures. Experimental results show that the cell performance is very sensitive to the oxygen concentration in the air cathode. The cell performance measurement results revealed that the cell resistance was very large at room temperature but decreased sharply with increasing temperatures. It was found that the cell resistances are the critical issue to show any significant discharge capacity at room temperature. Since cell resistances are very low at high temperature that's why lithium-air battery cells are performing much better at elevated temperature. It was also found that the lack of robust interfacial contact among solid electrolyte, air cathode and metallic lithium anode are the primary factor for the cell's high internal resistances. It was also observed that the discharge curve of the battery cell was much smoother once the cell internal resistance issues were resolved efficiently, and the cell was able to discharge at above $2.0 \mathrm{~V}$ for up to 40 hours. It implied that the issue of interfacial contact resistances must have to be resolved with utmost care in order to have better performing lithium-air battery cell. Further improvement of lithium-air battery cell performance based on the results obtained in this investigation will be conducted in a future study.

\section{Acknowledgements}

This work is accomplished under the funding support provided by the U.S. Department of Energy (DOE)-Renewable Energy Program, grant award number DE-EE 0003109.

\section{References}

[1] USCAR - United States Council for Automotive Research LLC. http://www.uscar.org

[2] Linden, D. and Reddy, T.B. (2002) Handbook of Batteries. McGraw Hill, New York, 41-45.

[3] Scrosati, B., Hassoun, J. and Sun, Y.-K. (2011) Lithium Ion Batteries. A Look into the Future. Journal of Energy and Environmental Science, 4, 3287-3295. http://dx.doi.org/10.1039/c1ee01388b

[4] Anderman, M. (2011) PHEV and EV Battery Technology Status and Vehicle and Battery Market Outlook. AABC Europe.

[5] Whittingham, M.S. (2004) Lithium Batteries and Cathode Materials. Journal of Chemistry Review, 104, 4271-4301. http://dx.doi.org/10.1021/cr020731c

[6] Pistoia, G. (2005) Batteries for Portable Devices. Elsevier, London.

[7] Zhang, J.-G., Wang, D., Xu, W., Xiao, J. and Williford, R.E. (2010) Ambient Operation of Li/Air Batteries. Journal of Power Sources, 195, 4332-4337. http://dx.doi.org/10.1016/j.jpowsour.2010.01.022

[8] Zheng, J.P., Liang, R.Y., Hendrickson, M. and Plichta, E.J. (2008) Theoretical Energy Density of Li-Air Batteries. Journal of Electrochemical Society, 155, A432-A437. http://dx.doi.org/10.1149/1.2901961

[9] Wang, D., Xiao, J., Xu, W. and Zhang, J.-G. (2010) High Capacity Pouch Type Li-Air Batteries. Journal of Electrochemical Society, 157, A760-A764. http://dx.doi.org/10.1149/1.3414828

[10] Girishkumar, G., McCloskey, B., Luntz, A. C., Swanson, S. and Wilcke, W. (2010) Lithium-air battery: promise and challenges, Journal of Physical Chemistry Letters, 1, 2193-2203. http://dx.doi.org/10.1021/jz1005384

[11] Jung, H.G., Hassoun, J., Park, J.B., Yang-Kook Sun, Y.K. and Scrosati, B. (2012) An Improved High-Performance Lithium-Air Battery. Nature Chemistry, 40, 579-585. http://dx.doi.org/10.1038/nchem.1376

[12] Beattie, S.D., Manolescu, D. M. and Blair, S.L. (2009) High Capacity Lithium-Air Cathodes. Journal of Electrochemical Society, 156, A44-A47. http://dx.doi.org/10.1149/1.3005989

[13] McCloskey, B.D., Bethune, D.S., Shelby, R.M., Girishkumar, G. and Luntz, A.C. (2011) Solvents' Critical Role in Nonaqueous Lithium-Oxygen Battery Electrochemistry. Journal of Physical Chemistry Letter, 2, 1161. http://dx.doi.org/10.1021/jz200352v

[14] Zhang, T. and Zhou, H. (2013) A Reversible Long-Life Lithium-Air Battery in Ambient Air. Nature Communications, 4, 1817. http://dx.doi.org/10.1038/ncomms2855

[15] Elia, G.A. and Hassoun, J. (2015) A Polymer Lithium-Oxygen Battery, Scientific Reports, 5, 12307. 
http://dx.doi.org/10.1038/srep12307

[16] Li, F., Kitaura, H. and Zhou, H. (2013) The Pursuit of Rechargeable Solid-State Li-Air Batteries. Journal of Energy and Environmental Science, 6, 2302. http://dx.doi.org/10.1039/c3ee40702k

[17] Balaish, M., Peled, E., Golodnitsky, D. and Ein-Eli, Y. (2015) Liquid-Free Lithium-Oxygen Batteries. Angewandte Chemie International Edition, 54, 436. http://dx.doi.org/10.1002/ange.201408008

[18] Jung, K.N., Lee, J.I., Jung, J.H., Shin, K.H. and Lee, J.W. (2014) A Quasi-Solid-State Rechargeable Lithium-Oxygen Battery Based on a Gel Polymer Electrolyte with an Ionic Liquid. Chemical Communications, 50, 5458. http://dx.doi.org/10.1039/c4cc01243g

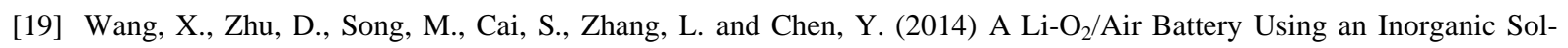
id-State Air Cathode. ACS Applied Materials and Interfaces, 6, 11204. http://dx.doi.org/10.1021/am501315n

[20] Nadège Bonnet-Mercier, N., Raymond A. Wong, R. A., Morgan L. Thomas, M.L., Arghya Dutta, A., Keisuke Yamanaka, K., Chihiro Yogi, C., Toshiaki Ohta, T. and Hye Ryung Byon, H.R. (2014) A Structured Three-Dimensional Polymer Electrolyte with Enlarged Active Reaction Zone for Li-O 2 Batteries. Scientific Reports, 4, 7127. http://dx.doi.org/10.1038/srep07127

[21] Shin, J.-H., Henderson, W.A. and Passerini, S. (2005) PEO-Based Polymer Electrolytes with Ionic Liquids and Their Use in Lithium Metal-Polymer Electrolyte Batteries. Journal of The Electrochemical Society, 152, A978. http://dx.doi.org/10.1149/1.1890701

[22] Appetecchi1, G.B., Crocel, F., Hassounl, J., Salomon, M. and Scrosati1, B. (2003) Hot-Pressed, Dry, Composite, PEO-Based Electrolyte Membranes: I. Ionic Conductivity Characterization. Journal of Power Sources, 114, 105. http://dx.doi.org/10.1016/S0378-7753(02)00543-8

[23] Aetukuri, N.B., McCloskey, B.D., García, J.M., Krupp, L.E., Viswanathan, V. and Luntz, A. C. (2015) Solvating Additives Drive Solution-Mediated Electrochemistry and Enhance Toroid Growth in Non-Aqueous $\mathrm{Li}_{2} \mathrm{O}_{2}$ Batteries. $\mathrm{Na}$ ture Chemistry, 7, 50. http://dx.doi.org/10.1038/nchem.2132

[24] Black, R., Oh, S.H., Lee, J.H., Yim, T., Adams, B. and Nazar, L.F. (2012) Screening for Superoxide Reactivity in Li- $\mathrm{O}_{2}$ Batteries: Effect on $\mathrm{Li}_{2} \mathrm{O}_{2} / \mathrm{LiOH}$ Crystallization. Journal of American Chemical Society, 134, 2902-2905. http://dx.doi.org/10.1021/ja2111543 